\title{
Liquefaction severity map for Aksaray city center (Central Anatolia, Turkey)
}

\author{
A. Yalcin ${ }^{1}$, C. Gokceoglu ${ }^{2}$, and H. Sönmez ${ }^{2}$ \\ ${ }^{1}$ Department of Geological Engineering, Applied Geology Division, Aksaray University, 68100, Aksaray, Turkey \\ ${ }^{2}$ Department of Geological Engineering, Applied Geology Division, Hacettepe University, 06800, Beytepe, Ankara, Turkey
}

Received: 27 March 2008 - Revised: 7 May 2008 - Accepted: 8 May 2008 - Published: 7 July 2008

\begin{abstract}
Turkey having a long history of large earthquakes have been subjected to progressive adjacent earthquakes. Starting in 1939, the North Anatolian Fault Zone (NAFZ) produced a sequence of major earthquakes, of which the Mw 7.4 earthquake that struck western Turkey on $17 \mathrm{Au}-$ gust 1999. Following the Erzincan earthquake in 1992, the soil liquefaction has been crucial important in the agenda of Turkey. Soil liquefaction was also observed widely during the Marmara and the Düzce Earthquake in 1999 (Sönmez, 2003). Aksaray city center locates in the central part of Turkey and the Tuzgolu Fault Zone passes through near the city center. The fault zone has been generated to moderate magnitude earthquakes. The geology of the Aksaray province basin contains Quaternary alluvial deposits formed by gravel, sand, silt, and clay layers in different thickness. The Tuzgolu Fault Zone (TFZ) came into being after the sedimetation of alluvial deposits. Thus, the fault is younger from lithological units and it is active. In addition, the ground water level is very shallow, within approximately $3 \mathrm{~m}$ from the surface. In this study, the liquefaction potential of the Aksaray province is investigated by recent procedure suggested by Sonmez and Gokceoglu (2005). For this purpose, the liquefaction susceptibility map of the Aksaray city center for liquefaction is presented. In the analysis, the input parameters such as the depth of the upper and lower boundaries of soil layer, SPT-N values, fine content, clay content and the liquid limit were used for all layers within $20 \mathrm{~m}$ from the surface. As a result, the category of very high susceptibility liquefaction class was not observed for the earthquake scenario of Ms=5.2, 4.9\% of the study area has high liquefaction susceptibility. The percentage of the moderately, low,
\end{abstract}

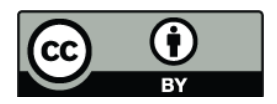

Correspondence to: A. Yalcin (ayalcin@aksaray.edu.tr) and very low liquefied areas are $28.2 \%, 30.2 \%$, and $36.3 \%$, respectively. The rank of non-liquefied susceptibility area is less than $1 \%$.

\section{Introduction}

Turkey has a long history of large earthquakes along the North Anatolian Fault Zone (NAFZ). The Anatolian Block is moving westward by lateral extrusion as a consequence of north-south convergence between Africa-Arabia and Eurasia Plates (Sengor et al., 1985). The compression of the Anatolian Block is responsible for complex deformation of the North Anatolian Fault Zone (NAFZ) that causes major earthquakes along the fault (Fig. 1). The Tuzgolu (Salt Lake) Fault Zone is one of the main tectonic elements of the Central Anatolia. It extends from the Tuzgolu to the Aksaray city center. The associations between the Tuzgolu Fault Zone and the alluvial deposits have been threaten to the Aksaray city center. Aksaray city is an place that growing up 400\% exponential in last twenty years (Turkish Statistical Institute, 2007). However, geotechnical assessment has been got behind in the new residential areas. There is a liquefaction potential in the place due to appropriate materials, high level ground water, and earthquake hazard. For this reason, suitable site selection and planning for settlement areas and other engineering construction, assessment of liquefaction potential of a liquefactionprone area is one of the important missions in geotechnical engineering as in the Aksaray city center (Fig. 2). Several methods were recommended to evaluate the liquefaction potential of sandy soils due to earthquakes (Iwasaki et al., 1982). The experimental criterion based on SPT-N values has been most popular or commonly preferred for evaluating the liquefaction assessments in most countries and in Turkey.

Published by Copernicus Publications on behalf of the European Geosciences Union. 


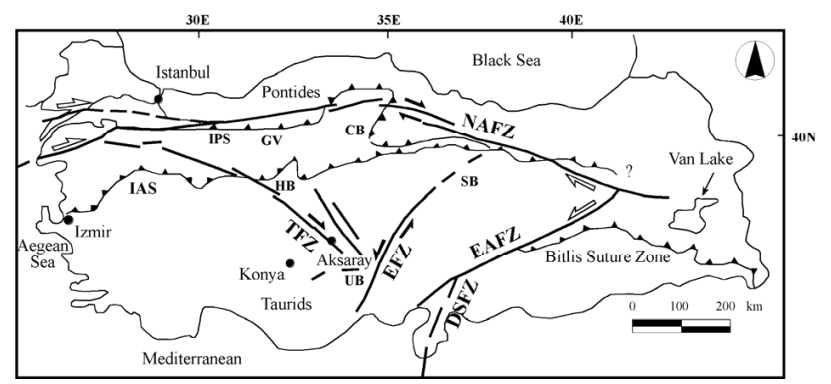

Fig. 1. The major basins and tectonic elements of the Central Anatolia (NAFZ- the North Anatolian Fault Zone, EAFZ- the East Anatolian Fault Zone, TFZ- the Tuzgolu Fault Zone, EFZ- the Ecemis Fault Zone, DSFZ- the Dead Sea Fault Zone, IAS- the IzmirAnkara Structure Zone, IPS- the Intrapontide Structure Zone, GVthe Galatian Volcanics, CB- the Cankiri Basin, SB- the Sivas Basin, UB- the Ulukisla Basin) (after Cemen et al., 1999).

Seed and Idriss (1971) proposed a simplified procedure based on SPT-N values for the assessment of liquefaction resistance of soils after two large and catastrophic earthquakes occurred in Alaska and in Niigata (Japan) in 1964. The original simplified procedure based on empirical rules has been modified and improved over the years (Seed, 1983; Seed et al., 1985; Seed and DeAlba, 1986; Seed and Handler, 1990). The factor of safety against liquefaction $\left(F_{L}\right)$ on the basis of the SPT is designated by the ratio of the cyclic resistance ratio (CRR) to cyclic stress ratio (CSR). While a soil layer with a factor of safety $\left(F_{L}\right)$ greater than 1.2 and between 1.0 and 1.2 are defined as non-liquefied and marginally liquefiable, respectively, soil with an $F_{L}$ less than 1.0 is considered liquefiable (Ulusay and Kuru, 2003). Determining the $F_{L}$ for a soil layer gives some information of liquefaction but it is a not adequate appliance for evaluation of liquefaction severity. In addition, $F_{L}$ is not a functional parameter to arrange liquefaction severity maps for liquefaction-prone areas. In this study, factor of safety $\left(F_{L}\right)$, probability of liquefaction $\left(P_{L}\right)$, and liquefaction severity index $\left(L_{S}\right)$ relations were explicated and a liquefaction susceptibility map for liquefaction-prone areas in Aksaray, Turkey is prepared by considering the liquefaction severity categories.

\section{Geological and hydrogeological characteristics of the study area}

The geology of the Aksaray province is dominated by Quaternary alluvial sediments. Figure 3 shows the simplified geological map of the Aksaray city. The rock units in Aksaray region belong to Paleocene-Eocene, Oligo-Miocene, Pliocene, and Quaternary periods. The rock units of the Paleocene-Eocene are found in the north of the centrum, namely, in Yunuskent, Ciftlik, and Hamambogazi regions. They show a volcano-sedimentary stratigraphy and consist

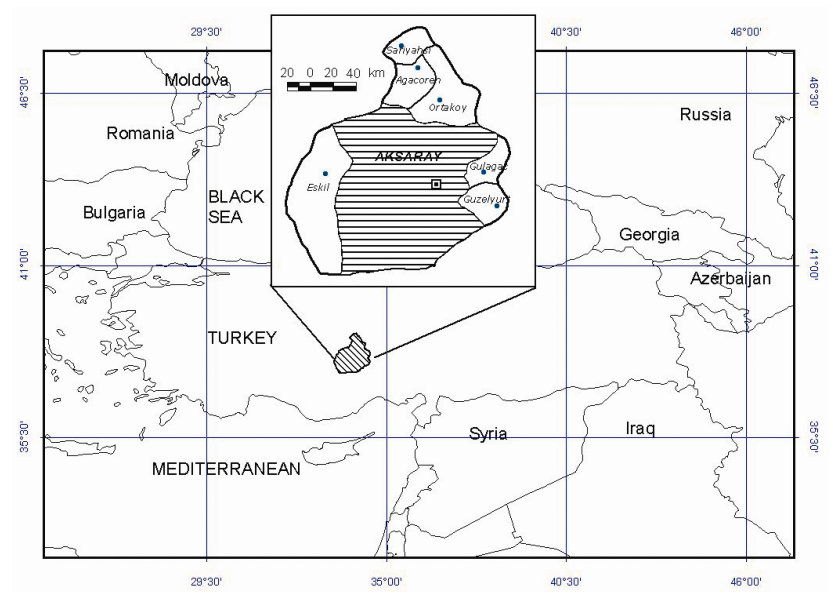

Fig. 2. Location map of the study area.

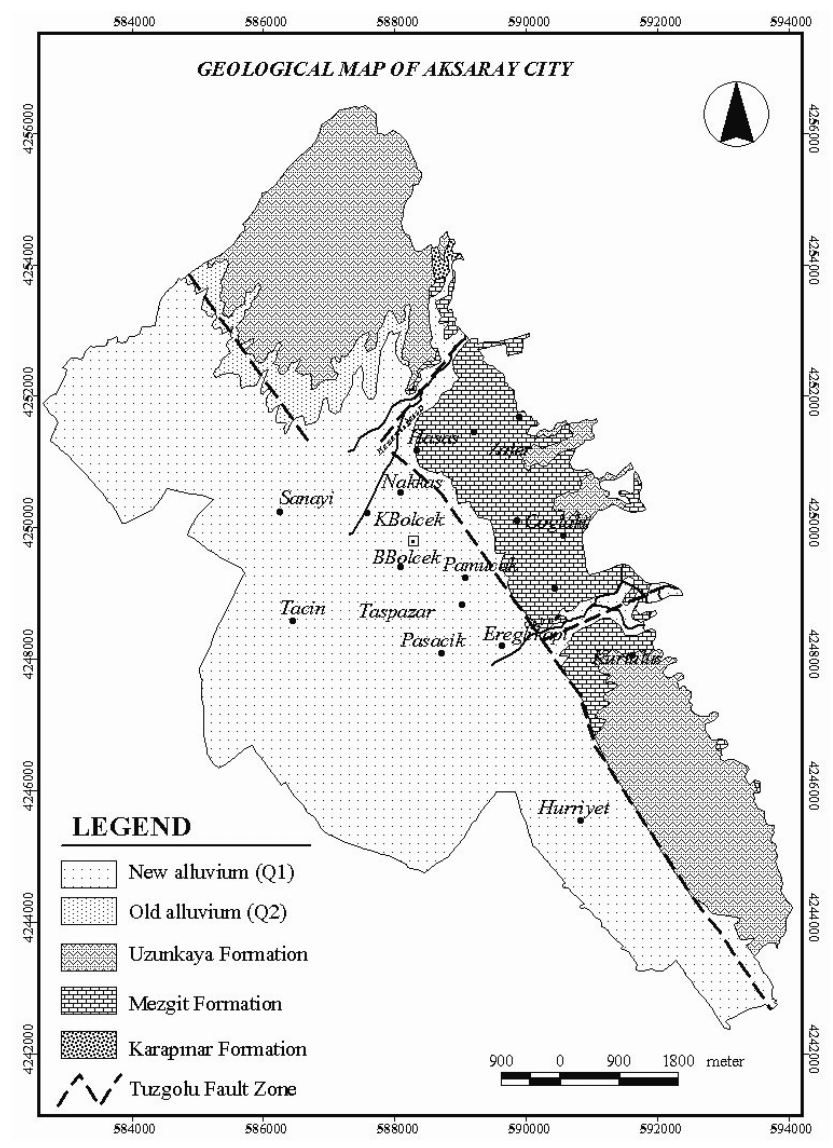

Fig. 3. The geological map of the study area (after Gullu, 2003).

of yellow, yellow-green sandstone and evaporite. The OligoMiocene series trending NW-SE are characterized by conglomerate, sandstone, mudstone, and claystone which are known as Mezgit Formation (Tromp, 1942), crop out in the Zafer, Kurtulus, and Bedirmuhtar regions. Sandstone, siltstone, marl and mudstone of Pliocene known as Uzunkaya 
Formation (Beekman, 1966) are observed in the north and east of the region. The formation overly the most expansive area after Quaternary units.

The Quaternary deposits are described by the new and old alluvial soils. Old alluvium soils are found as a narrow strip in the north of the Aksaray city, namely, in Yenimahalle, Somuncubaba, and Ciftlik regions. It is overlain by the new alluvial soils in the city center towards south and south east. The Aksaray city is a broad, flat, Tuzgolu Fault bounded plain traversed by two main rivers, the Ulu River in the east and the Hamambogazi River in the northeast. The Ulu River comes from the east to the plain, the slope decreases from a rather steep descent in the mountains to the about flat surface of the basin floor. This abrupt change of slope causes rapid deposition of sediment. The deposition and redistribution of the Quaternary sediments carried into the basin by these rivers has led to the gathering of thick unconsolidated alluvial plain deposits composed of intercalated gravel, sand silt and clay layers. Because of the rapid and dynamic sedimentation process, the deposits vary from well to poorly graded and are generally loosely compacted.

Considering the quality of the data required for liquefaction analysis, seventy-seven boreholes were selected from the boreholes drilled by Orta Anadolu Jeoloji Muh. Company in the Aksaray city for geotechnical purposes. The ground water table in the drill holes was measured and the groundwater level generally ranges between 3 and $9.5 \mathrm{~m}$ below the ground surface. The existence of a groundwater table within $10 \mathrm{~m}$ from surface and loose granular alluvial deposits increases the susceptibility of liquefaction potential of the soils.

\section{Tectonic setting}

The major tectonic plates in the eastern Mediterranean region are shown in Fig. 1. The Anatolian block has been moving to the west along the North Anatolian Fault Zone (NAFZ) since the Pliocene (Barka, 1997). The important tectonic features within the area are the Tuzgolu Fault Zone, the Yeniceoba Fault Zone, the Cihanbeyli Fault Zone (Fig. 4) and in the south-east, the Ecemis Fault Zone (Fig. 1). In addition, the Central Anatolian Volcanic Province (CAVP) (Fig. 4) is situated between Kirsehir and Nigde massifs that collectively constitute the Central Anatolian crystallen complex, and CAVP of Neogene-Quaternary age extendes as a volcanic axis of about $300 \mathrm{~km}$ in NE-SW direction in the Central Anatolia, Turkey. The formation and evaluation of the CAVP has been usually attributed to the convergence between Afro-Arabian and Eurasian plates (Ercan et al., 1990, Goncuoglu and Toprak, 1992). The major Tuzgolu Fault cuts across the CAVP with a NW-SE direction. The Tuzgolu Fault Zone is a NW-SE trending intracontinental fracture zone, approximately 190 to $200 \mathrm{~km}$ long and 5 to $25 \mathrm{~km}$ wide, extending from north of Tuzgolu to south-east of Aksaray (Dirik and Goncuoglu, 1996). In the north-western part of

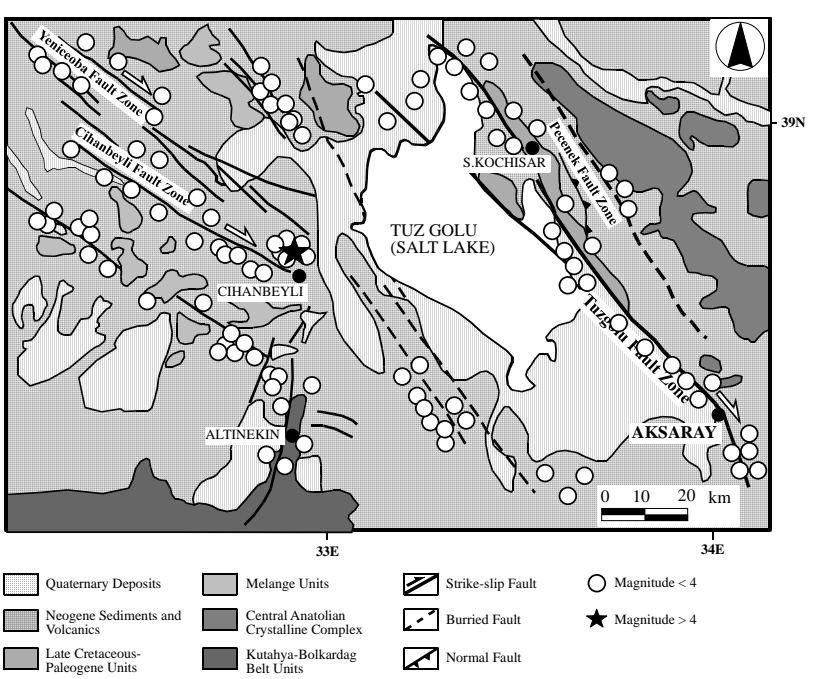

Fig. 4. The seismogeological map of the Tuzgolu basin and its close vicinity (after Cemen et al., 1999).

the Tuzgolu, two parallel fault zones extend from Yeniceoba and Cihanbeyli northwestward, namely, the Yeniceoba Fault Zone and the Cihanbeyli Fault Zone. These faults bring Paleozoic basement rocks and overlying sedimentary succession to the surface (Cemen at al., 1999). The Ecemis Fault Zone is one of the major structures of Turkey and a NE-SW trending normal-oblique left-lateral strike-slip characteristic is shown. Approximately 2 to $15 \mathrm{~km}$ wide, extending from north of Mersin to south-west to Sivas-Refahiye (Dirik and Goncuoglu, 1996). These fault zones have been generated to earthquake different magnitude. Besides, Fig. 4 shows the earthquake in Tuzgolu basin at the last one year, at the same time in the Tuzgolu, the Yeniceoba, the Cihanbeyli, and the Ecemis Fault zones.

\section{Liquefaction assessment}

Liquefaction occurs in saturated loose soils, that is, soil layers within $20 \mathrm{~m}$ from ground surface with the $F_{L}$ values less than 1.0 are appraised as liquefiable. The condition $F_{L}>1$ indicate that the soil is classified as non-liquefiable, if $F_{L}<1$ show that the unit is categorized liquefiable. However still, these limits are theoretical assets and don't adduce to absolute results. For realistic liquefaction assessments, detailed geological and seismological data sets are required, such as SPT-N values, clay content (CC), fines content (FC), liquid limits for soils etc. In addition, liquefaction potential index $\left(L_{I}\right)$ and its severity categories were suggested by Iwasaki et al. (1982) for resolving restriction of $F_{L}$. In this research, Iwasaki et al. (1982) proposed a liquefaction index $\left(L_{I}\right)$ is 
Table 1. Liquefaction potential categories suggested by Iwasaki et al. (1982).

\begin{tabular}{ll}
\hline Liquefaction index $\left(L_{I}\right)$ & Liquefaction potential \\
\hline 0 & Very low \\
$0<L_{I} \leq 5$ & Low \\
$5<L_{I} \leq 15$ & High \\
$15>L_{I}$ & Very high \\
\hline
\end{tabular}

Table 2. Liquefaction severity categories based on $L_{S}$ (Sonmez and Gokceoglu, 2005).

\begin{tabular}{ll}
\hline Liquefaction index $\left(L_{I}\right)$ & Liquefaction potential \\
\hline 0 & $\begin{array}{l}\text { Non-liquefiable } \\
\left.\text { (based on } F_{L} \geq 1.411\right)\end{array}$ \\
$0<L_{I} \leq 2$ & Low \\
$2<L_{I} \leq 5$ & Moderate \\
$5<L_{I} \leq 15$ & High \\
$15>L_{I}$ & Very high \\
\hline
\end{tabular}

explained by the succeeding equations.

$L_{I}=\int_{0}^{20} F(z) W(z) d z$

$F(z)=1-F_{L}$ for $F_{L}<1.0$

$F(z)=0$ for $F_{L} \geq 1.0$

$F(z)=10-0.5 z$ for $z<1.0$

$W(z)=0$ for $z>20 \mathrm{~m}$

where $z$ is the depth from the ground surface in meters. Iwasaki et al. (1982) proposed four classes termed as very low, low, high, and very high for liquefaction severity (Table 1). Non-liquefiable group could not be discriminated by Iwasaki et al. (1982), to bring expansion these issue, Sonmez (2003) modified $F(z)$ term appearing the equation of $L_{I}$ by considering the threshold value of 1.2 between the nonliquefiable and marginally liquefied categories as follow:

$F(z)=0$ for $F_{L} \geq 1.2$

$F(z)=2 \times 10^{6} e_{L}^{-18.427 F}$ for $1.2>F_{L}>0.95$

$F(z)=1-F_{L}$ for $F_{L}<0.95$

As a result of evaluations, Sonmez (2003) proposed new classification categories called as non-liquefiable, low, moderate, high, and very high for liquefaction potential (Table 2).

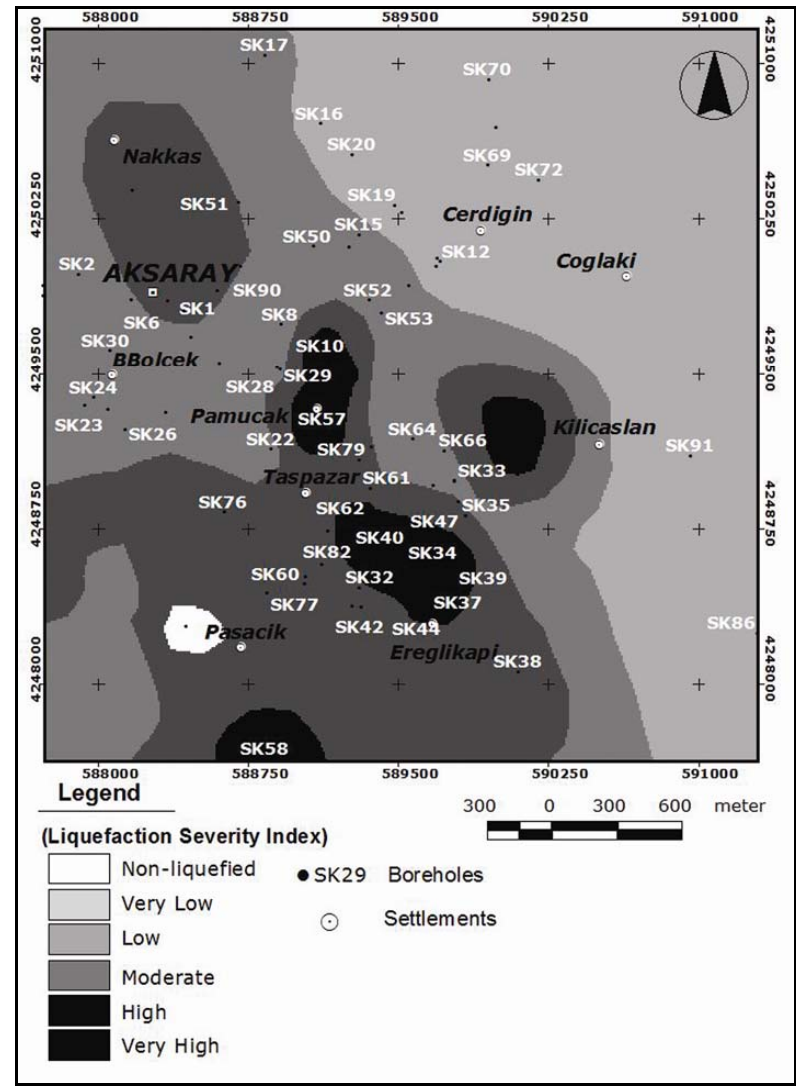

Fig. 5. The liquefaction severity map of Aksaray city center.

The probabilities of soil liquefaction are related to the value of $F_{L}$ (Chen and Juang, 2000). The probability of liquefaction has been calculated by $P_{L}$ equation (Juang et al., 2003). This value strolls from zero to one as a function of $F_{L}$.

$P_{L}=\frac{1}{1+\left(F_{L} / 0.96\right)^{4.5}}$

Chen and Juang (2000) suggested to the classification of probability of liquefaction (Table 3). Juang et al. (2003) substituted the $F(z)$ illustrate of the $L_{I}$ index suggested by Iwasaki et al. (1982) with $P_{L}$ and also renamed $L_{I}$ as liquefaction risk index $\left(I_{R}\right)$.

$I_{R}=\int_{0}^{20} P_{L}(z) W(z) d z$

Iwasaki et al. (1982), Sonmez (2003), and Lee et al. (2003) were suggested to the liquefaction indices using for the preparation of liquefaction susceptibility maps. Therefore, to bring new perspective in this issue, Sonmez and Gokceoglu (2005), the term liquefaction severity index $\left(L_{S}\right)$ is preferred instead of liquefaction risk index $\left(L_{R}\right)$ suggested by Lee et al. (2003). 
Table 3. The classification of the liquefaction probability based on $P_{L}$ (Chen and Juang, 2000).

\begin{tabular}{lll}
\hline $\begin{array}{l}\text { Probability }\left(P_{L}\right) \\
\text { ranges }\end{array}$ & Description & $\begin{array}{l}\text { Factor of safety }\left(F_{L}\right) \text { ranges calcu- } \\
\text { lated from Eq. } 4\end{array}$ \\
\hline $0.85 \leq P_{L}<1.00$ & Almost certain that it will liquefy & $0.653 \geq F_{L}>0.000$ \\
$0.65 \leq P_{L}<0.85$ & Very likely & $0.837 \geq F_{L}>0.653$ \\
$0.35 \leq P_{L}<0.65$ & Liquefaction/non-liquefaction is equally likely & $1.102 \geq F_{L}>0.837$ \\
$0.15 \leq P_{L}<0.35$ & Unlikely & $1.411 \geq F_{L}>1.102$ \\
$0.00 \leq P_{L}<0.15$ & Almost certain that it will not liquefy & $\infty \geq F_{L}>1.411$ \\
\hline
\end{tabular}

Table 4. Liquefaction severity categories based on $L_{S}$ (Sonmez and Gokceoglu, 2005).

\begin{tabular}{ll}
\hline Liquefaction severity $\left(L_{S}\right)$ & Description \\
\hline $85 \leq L_{S}<100$ & Very high \\
$65 \leq L_{S}<85$ & High \\
$35 \leq L_{S}<65$ & Moderate \\
$15 \leq L_{S}<35$ & Low \\
$0<L_{S}<15$ & Very low \\
$L_{S}=0$ & Non-liquefiable \\
\hline
\end{tabular}

Sonmez and Gokceoglu (2005) was explained in the following stages for construction of the liquefaction severity classification:

Stage 1: $W(z)=10-0.5 z$ is put into the Eq. 5 and it was rewritten.

$$
L_{S}=\int_{0}^{20} P_{L}(z)(10-0.5 z) d z
$$

Stage 2: $F_{L}$ value appearing in $P_{L}(z)$ equation is assumed as a constant from the ground surface to a depth of $20 \mathrm{~m}$, and Eq. 6a was solved.

$L_{S}=\left.P_{L}(z)\left(10 z-\frac{z^{2}}{4}\right)\right|_{0} ^{20}$

$L_{S}=100 P_{L}(z)$

Stage 3: Boundary values of $L_{S}$ are derived from Eq. $6 \mathrm{c}$ for each $P_{L}$ value given in Table 3 , and tabulated in Table 4 with liquefaction susceptibility descriptions.

As a result of these evaluation, Sonmez (2003) proposed as non-liquefiable soil layer if $F_{L}>1.2$ and but, as non-liquefiable limit was suggested by Sonmez and Gokceoglu (2005) to much more meaningful values $\left(F_{L}=1.411\right)$ considering the function the probability of liquefaction given in Eq. 4. The $P_{L}(z)$ term of $L_{S}$ is assumed as equal to zero for the layer with $F_{L}>1.411$. Youd et al. (2001) pointed out if the corrected SPT-N value $\left(\mathrm{N}_{1(60) c s}\right)$ is greater

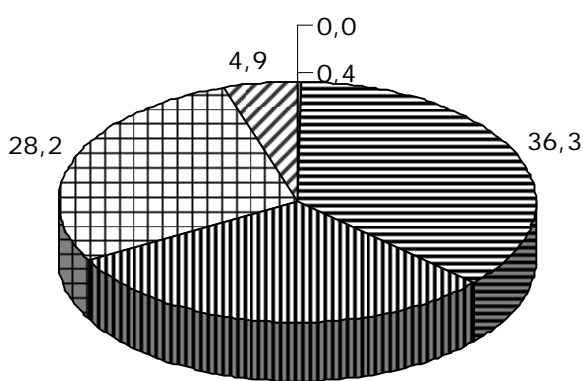

30,2

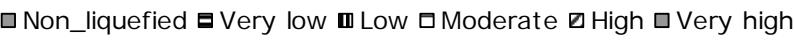

Fig. 6. Pie charts showing the areas of the severity zones.

than 30 in the SPT-based method, $F_{L}$ couldn't be designated, and the predicted the cyclic resistance ratio (CRR) for the soil layer involving more than $35 \%$ fines content may be protective. For that reason, Youd et al. (2001) suggest that the rectifications based on fines content should be used with engineering decision and concern. Similarly, soil layer with $F_{L}<1.0$ can be assessed as non-liquefiable based on some criteria such as offered by Finn et al. (1994), and Andrews and Martin (2000), which consider Clay Content and Liquid Limit. Therefore, if the soil layer is appraised as nonliquefiable based on the futures of fines, the $P_{L}(\mathrm{z})$ term is assumed as equal to zero to distinguish non-liquefiable area (Table 5) (Sonmez and Gokceoglu, 2005).

The equations to be used for the designation of $L_{S}$ are given below.

$$
\begin{aligned}
& L_{S}=\int_{0}^{20} P(z) W(z) d z \\
& P_{L}(z)=\frac{1}{1+\left(F_{L} / 0.96\right)^{4.5}} \text { for } F_{L} \leq 1.411 \\
& P_{L}(z)=0 \text { for } F_{L}>1.411
\end{aligned}
$$

or the soil layer with $F_{L} \leq 1.411$ can be considered as nonliquefiable layer considering Clay Content and Liquid limit.

In Eq. 6, the term of $W(z)$ is as same as in Eq. 2c and d. 
Table 5. Liquefaction severity index values for Aksaray city.

\begin{tabular}{|c|c|c|c|c|c|}
\hline \multirow{2}{*}{$\begin{array}{l}\text { Borehole } \\
\text { no }\end{array}$} & \multicolumn{2}{|c|}{ Coordinates } & \multirow{2}{*}{$\begin{array}{l}\text { Depth of } \\
\text { GWT (m) }\end{array}$} & \multirow[t]{2}{*}{$L_{S}$} & \multirow{2}{*}{$\begin{array}{l}\text { Liquefaction } \\
\text { severity class }\end{array}$} \\
\hline & $\mathrm{N}$ & $\mathrm{E}$ & & & \\
\hline SK-1 & 588490.11 & 4249678.07 & 3.50 & 38.07 & Moderate \\
\hline SK-2 & 587946.89 & 4249986.41 & 3.50 & 20.14 & Low \\
\hline SK-3 & 587774.16 & 4249930.89 & 4.00 & 37.78 & Moderate \\
\hline SK-4 & 588458.99 & 4249808.82 & 4.50 & 32.70 & Low \\
\hline SK-5 & 588194.23 & 4250036.17 & 5.00 & 37.32 & Moderate \\
\hline SK-6 & 588379.71 & 4249854.81 & 4.00 & 27.30 & Low \\
\hline SK-7 & 588203.61 & 4249862.04 & 3.50 & 31.36 & Low \\
\hline SK-8 & 588926.52 & 4249742.81 & 6.50 & 20.14 & Low \\
\hline SK-9 & 587774.74 & 4249879.11 & 3.50 & 20.14 & Low \\
\hline SK-10 & 589120.91 & 4249589.49 & 4.50 & 70.02 & High \\
\hline SK-11 & 589675.12 & 4250025.33 & 9.00 & 30.81 & Low \\
\hline SK-12 & 589697.55 & 4250046.91 & 9.00 & 20.14 & Low \\
\hline SK-13 & 589507.82 & 4250282.49 & 7.50 & 28.21 & Low \\
\hline SK-14 & 589682.98 & 4250060.33 & 8.50 & 20.14 & Low \\
\hline SK-15 & 589305.81 & 4250174.89 & 6.50 & 30.37 & Low \\
\hline SK-16 & 589117.31 & 4250712.45 & 5.50 & 20.14 & Low \\
\hline SK-17 & 588850.87 & 4251041.86 & 7.50 & 26.41 & Low \\
\hline SK-19 & 589477.64 & 4250318.51 & 6.00 & 19.87 & Low \\
\hline SK-20 & 589272.41 & 4250563.74 & 7.00 & 20.74 & Low \\
\hline SK-21 & 589543.11 & 4249930.59 & 5.00 & 39.20 & Moderate \\
\hline SK-22 & 588880.46 & 4249135.04 & 4.50 & 19.87 & Low \\
\hline SK-23 & 587977.31 & 4249348.74 & 3.00 & 22.16 & Low \\
\hline SK-24 & 588021.75 & 4249383.57 & 3.00 & 18.77 & Low \\
\hline SK-25 & 588092.17 & 4249328.41 & 3.50 & 48.16 & Moderate \\
\hline SK-26 & 588170.88 & 4249232.37 & 3.50 & 34.39 & Low \\
\hline SK-27 & 588628.49 & 4249551.16 & 4.50 & 20.14 & Low \\
\hline SK-28 & 588906.93 & 4249533.71 & 4.50 & 19.40 & Low \\
\hline SK-29 & 588921.34 & 4249523.35 & 4.50 & 20.14 & Low \\
\hline SK-30 & 588101.28 & 4249615.58 & 3.50 & 49.28 & Moderate \\
\hline SK-31 & 588367.62 & 4249314.04 & 4.00 & 21.21 & Low \\
\hline SK-32 & 589498.05 & 4248539.05 & 4.50 & 40.96 & Moderate \\
\hline SK-33 & 589766.61 & 4248980.71 & 5.50 & 62.10 & Moderate \\
\hline SK-34 & 589663.44 & 4248585.49 & 4.00 & 83.64 & High \\
\hline SK-35 & 589817.53 & 4248814.81 & 6.50 & 20.14 & Low \\
\hline SK-36 & 589579.28 & 4248380.61 & 4.50 & 36.67 & Moderate \\
\hline SK-37 & 589786.37 & 4248345.64 & 4.00 & 35.51 & Moderate \\
\hline SK-38 & 590075.49 & 4248059.98 & 3.00 & 25.39 & Low \\
\hline
\end{tabular}

\section{Liquefaction severity map of the Aksaray city center}

Following the 1999 Marmara earthquake, liquefaction falls over on the agenda of public opinion in Turkey, because, the most severe structural damages and loss of lives occurred during the 1999 Marmara Earthquake. There are several active tectonic sections in Turkey such as the North Anatolian Fault Zone, the East Anatolian Fault Zone, the West Anatolian Grabens, the Ecemis Fault Zone, the Tuzgolu Fault Zone, etc. The Aksaray city center locates near the Tuzgolu Fault Zone, a seismically active region in the Central Anatolian. In addition, loose granular alluvial deposits and close to surface groundwater table raise the liquefaction severity of the soils. For the analysis of liquefaction severity, a geological map of the Aksaray city was prepared and a total of 77 geotechnical boreholes performed by Orta Anadolu Jeoloji Muh. Company was assessed for the preparation of a liquefaction susceptibility map for the Aksaray city center. The SPT samples were implemented at depth intervals of $1.5 \mathrm{~m}$ from the first to the last boreholes, and the disturbed samples were used to describe grain-size distribution and Atterberg limits of the soils. The boundaries of the soil layer, SPT-N values, fines content, clay content and the liquid limit for all layers throughout boreholes were employed as input parame- 
Table 5. Continued.

\begin{tabular}{|c|c|c|c|c|c|}
\hline \multirow{2}{*}{$\begin{array}{l}\text { Borehole } \\
\text { no }\end{array}$} & \multicolumn{2}{|c|}{ Coordinates } & \multirow{2}{*}{$\begin{array}{l}\text { Depth of } \\
\text { GWT (m) }\end{array}$} & \multirow[t]{2}{*}{$L_{S}$} & \multirow{2}{*}{$\begin{array}{l}\text { Liquefaction } \\
\text { severity class }\end{array}$} \\
\hline & $\mathrm{N}$ & $\mathrm{E}$ & & & \\
\hline SK-39 & 589766.04 & 4248509.83 & 4.00 & 46.78 & Moderate \\
\hline SK-40 & 589400.98 & 4248658.59 & 5.00 & 49.16 & Moderate \\
\hline SK-41 & 589569.17 & 4248485.49 & 4.50 & 35.54 & Moderate \\
\hline SK-42 & 589313.36 & 4248372.76 & 5.50 & 27.45 & Low \\
\hline SK-43 & 589272.32 & 4248375.76 & 5.50 & 22.32 & Low \\
\hline SK-44 & 589582.85 & 4248365.92 & 4.50 & 37.19 & Moderate \\
\hline SK-47 & 589781.78 & 4248884.13 & 5.50 & 25.60 & Low \\
\hline SK-48 & 589302.25 & 4248465.97 & 4.00 & 45.77 & Moderate \\
\hline SK-49 & 588207.17 & 4250389.14 & 6.50 & 25.00 & Low \\
\hline SK-50 & 589085.87 & 4250120.48 & 5.00 & 45.70 & Moderate \\
\hline SK-51 & 588720.55 & 4250330.69 & 4.50 & 36.29 & Moderate \\
\hline SK-52 & 589351.26 & 4249860.15 & 6.50 & 20.14 & Low \\
\hline SK-53 & 589409.67 & 4249796.53 & 6.50 & 00.00 & Non-liquefied \\
\hline SK-54 & 589253.74 & 4250118.48 & 7.50 & 20.14 & Low \\
\hline SK-55 & 588728.72 & 4250022.79 & 5.00 & 27.39 & Low \\
\hline SK-57 & 589082.42 & 4249228.75 & 3.50 & 66.28 & High \\
\hline SK-58 & 588849.98 & 4247607.82 & 4.50 & 68.44 & Moderate \\
\hline SK-60 & 589039.13 & 4248483.07 & 3.00 & 36.30 & Moderate \\
\hline SK-61 & 589360.36 & 4248945.61 & 7.00 & 24.62 & Low \\
\hline SK-62 & 589265.89 & 4248799.12 & 5.50 & 62.26 & Moderate \\
\hline SK-63 & 589125.08 & 4248579.31 & 3.50 & 25.33 & Low \\
\hline SK-64 & 589563.44 & 4249183.54 & 8.00 & 20.14 & Low \\
\hline SK-65 & 589045.16 & 4248520.93 & 4.50 & 25.09 & Low \\
\hline SK-66 & 589713.55 & 4249129.32 & 6.00 & 35.94 & Moderate \\
\hline SK-68 & 588467.68 & 4248279.03 & 5.50 & 20.64 & Low \\
\hline SK-69 & 589926.98 & 4250511.33 & 9.50 & 20.14 & Low \\
\hline SK-70 & 589928.99 & 4250925.31 & 5.50 & 20.14 & Low \\
\hline SK-71 & 589973.46 & 4251222.36 & 9.00 & 20.14 & Low \\
\hline SK-72 & 590171.28 & 4250440.61 & 9.50 & 20.14 & Low \\
\hline SK-73 & 589965.03 & 4250692.45 & 9.50 & 20.14 & Low \\
\hline SK-76 & 588650.83 & 4248831.15 & 4.00 & 29.33 & Low \\
\hline SK-77 & 588857.81 & 4248439.09 & 4.50 & 30.73 & Low \\
\hline SK-78 & 589763.79 & 4248982.83 & 5.00 & 20.14 & Low \\
\hline SK-79 & 589301.91 & 4249085.08 & 5.50 & 20.14 & Low \\
\hline SK-81 & 589363.87 & 4249143.55 & 5.00 & 27.36 & Low \\
\hline SK-82 & 589151.46 & 4248739.21 & 4.00 & 30.13 & Low \\
\hline SK-86 & 591230.69 & 4248245.82 & 5.00 & 20.14 & Low \\
\hline SK-88 & 589661.24 & 4248958.29 & 6.00 & 20.14 & Low \\
\hline SK-90 & 588619.97 & 4249905.34 & 4.50 & 28.20 & Low \\
\hline SK-91 & 590905.79 & 4249102.36 & 6.00 & 20.14 & Low \\
\hline
\end{tabular}

ters to determine the liquefaction severity index. In addition, for preparing the liquefaction severity map, the magnitude of the scenario earthquake and the maximum horizontal acceleration were used. The Tuzgolu Fault Zone and around zones have been generated to average as 5.2 magnitudes so far. Due to this reason, the magnitude of the earthquake scenario was considered at 5.2. One more input parameter in the liquefaction analysis, the maximum ground acceleration $\left(a_{\max }\right)$, is introduced with great difficult. However, some re- searchers were proposed some equations for the maximum ground acceleration (Joyner and Boore, 1981; Fukushima et al., 1988; Inan et al., 1996; Aydan et al., 1996; Ulusay et al., 2004). Especially, Ulusay et al., (2004) displayed as comprehensive study related to iso-acceleration map of Turkey. In this study, the $a_{\max }$ values were calculated as approximately 300 gal for the Tuzgolu Fault Zone. The liquefaction severity indices for seventy-seven boreholes are calculated and given in Table 5. The liquefaction severity map of the Aksaray city 
center was generated by using triangulation with linear interpolation technique considering $L_{S}$ values and coordinates of boreholes (Fig. 5). As can be seen from Fig. 5, a large horizon from NW to SE is represented by high to moderate-low liquefaction severity classes. Also, the distribution areas of all severity zones for the earthquake scenario are presented in Fig. 6 as pie chart.

\section{Results and conclusion}

The evaluation of the liquefaction potential of a liquefactionprone area is one of the important issues in geotechnical earthquake engineering for assessment of site selection and planning studies. In this study, the concept of liquefaction severity index has been used for susceptibility mapping suggested by Sonmez and Gokceoglu (2005). For this aim, the Aksaray province, locating in the central part of Turkey and is passed through by the Tuzgolu Fault Zone, were evaluated for generation of the liquefaction severity map by considering for earthquake scenario $\mathrm{Ms}=5$.2. Consequently, the category of very high susceptibility liquefaction was not observed for the earthquake scenario of $\mathrm{Ms}=5.2$, however, $4.9 \%$ of the study area having high liquefaction susceptibility class. The percentage of the moderately liquefied took up too much area from the other class, $28.2 \%$. The low and very low liquefied areas are $30.2 \%$ and $36.3 \%$, respectively. The rank of non-liquefied susceptibility area is only less than $1 \%$.

Edited by: M. Contadakis

Reviewed by: K. Zorlu and another anonymous referee

\section{References}

Andrews, D. C. and Martin, G. R.: Criteria for liquefaction of silty sands, In: 12th World Conference on Earthquake Engineering, Auckland New Zealand, 2000.

Aydan, O., Sezaki, M., and Yarar, T.: The seismic characteristics of Turkish earthquakes, In: 11th Proc Int Con on Earthq Eng, Acapulco, Mexico, 1-8, 1996.

Barka, A.: Neotectonics of the Marmara region in active tectonics of Northwestern Anatolia, In: Schindler C, Pfister M (eds) The Marmara Poly-Project, Hochschulverlag AG an der ETH, Zurich, 55-87, 1997.

Beekman, P. H.: The volcanic activity of Pliocene and Quaternary era in Hasandagi-Melendizdagi regions, MTA Publications, 66, 88-104, 1966 (in Turkish).

Cemen, I., Goncuoglu, M. C., and Dirik, K.: Structural evalution of the Tuzgolu basin in central Anatolia, Turkey, The J of Geo, 107 693-706, 1999.

Chen, C. J. and Juang, C. H.: Calibration of SPT- and CPT-based liquefaction evaluation methods, In: Innovations and applications in geotechnical site characterization, edited by: Mayne, P.W., Hryciw, R., Vol. 97. Geotechnical Special Publication, ASCE, Reston, 49-64, 2000.

Dirik, K. and Goncuoglu, M. C.: Neotectonic characteristics of central Anatolia, Int. Geo. Rev., 38, 807-817, 1996.
Ercan, T., Fujitani, T., Matsuda, J. I., Tokel, S., Notsu, K., Ui, T., Can, B., Selvi, Y., Yildirim, T., Fisekci, A., Olmez, M., and Akbasli, A.: The origin and evolution of the Cenozoic volcanism of Hasandagi-Karacadag area (Central Anatolia), Bull Geomor., Turkey, 18, 39-54, 1990.

Finn, W. L., Ledbetter, R. H., and Wu, G.: Liquefaction in silty soils: design and analysis, Ground failures under seismic conditions, Geotechnical Special Publication No. 44, ASCE, Reston, 51-79, 1994.

Fukushima, Y., Tanaka, T., and Kataoka, S.:, A new attenuation relationship for peak ground accelerations, Proc. 9th WCCE, Tokyo, Japan, 1988.

Goncuoglu, M. C. and Toprak, V.: Neogene and Quaternary volcanism of Central Anatolia: A volcano-structural evaluation, Bull de la section de Volcanologie, 26, 1-6, 1992.

Gullu, B.: Geological-petrographical and geochemical investigation of magmatic rocks around mamasun area (Aksaray), MSc Thesis, Aksaray, 2003.

Inan, E., Colakoglu, Z., Koc, N., Bayulke, N., and Coruh, E.: Catalogue of earthquakes between 1976-1996 with acceleration records, ERD, General Directorate of Disaster Affairs of Public Works and Settlement Ankara, 150, 1996.

Iwasaki, T., Tokida. K., Tatsuoka, F., Watanabe, S., Yasuda, S., and Sato, H.: Microzonation for soil liquefaction potential using simplified methods, vol. 3, In: Proceedings of 3th international conference on microzonation, Seattle, 1319-1330, 1982.

Joyner, W. B. and Boore, D. M.: Peak horizontal acceleration and velocity from strong-motion records from the 1997 Imperial Valley, California earthquake, Bull Seis Am, 71(6), 2011-2038, 1981.

Juang, C. H., Yuan, H., Lee, D. H., and Lin, P. S.: A simplified CPT-based method for evaluating liquefaction potential of soils, J. Geotech. Geoenviron. Eng., 129, 66-80, 2003.

Lee, D. H., Ku, C. S., and Yuan, H.: A study of the liquefaction risk potential at Yuanlin. Taiwan Engineering Geology, 71, 97-117, 2003.

Seed, H. B.: Earthquake-resistant design of earth dams. In: Proceedings of Symp. Seismic Des. of earth dams and caverns, ASCE, New York, 41-64, 1983.

Seed, H. B. and DeAlba, P.: Use of the SPT and CPT tests for evaluating the liquefaction resistance of sands, In: Use of in-situ tests in geotechnical engineering, ASCE Geotechnical Special Publication, 6, 281-302, 1986.

Seed, H. B. and Hander, L. F.: SPT-based analysis of cyclic pressure generation and undrained residual strength, In: Proceedings of H. Bolton Seed memorial symposium, BiTech Publishers Ltd., 351-376, 1990.

Seed, H. B., Idriss, I. M.: Simplified procedure for evaluating soil liquefaction potential, J. Soil Mech. Found. Div. ASCE 97(SM9), 1249-1273, 1971.

Seed, H. B., Tokimatsu, K., Hander, L. F., and Chung, R. M.: Influence of SPT procedures in soil liquefaction resistance evaluations, J. Geotech. Eng. Div. ASCE 111(2), 1425-1445, 1985.

Sengor, A. M. C., Gorur, N., and Saroglu, F.: Strike-slip faulting and related basin formation in zones of tectonic escape: Turkey as a case study, Society of Economic Paleontologists and Mineralogists Special Publication No. 37, 227-264, 1985.

Sonmez, H.: Modification to the liquefaction potential index and liquefaction susceptibility mapping for a liquefaction-prone area 
(Inegol-Turkey), Environ Geology, 44(7), 862-871, 2003.

Sonmez, H. and Gokceoglu, C.: A liquefaction severity index suggested for engineering practice, Environ. Geology., 48, 81-91, 2005.

Tromp, S. W.: Geological characteristics of Nigde - Incesu - Tuzgolu regions, No 1456 MTA Institute, Ankara, 1942 (in Turkish).

Turkish Statistical Institute, http://www.turkstat.gov.tr, access: 15 August 2007.

Ulusay, R. and Kuru, T.: 1998 Adana-Ceyhan (Turkey) earthquake and a preliminary microzonation based on liquefaction potential for Ceyhan Town, Natural Hazards 32, 59-88, 2004.
Ulusay, R., Tuncay, E., Sonmez, H., and Gokceoglu, C.: An attenuation relationship based on Turkish strong motion data and iso-acceleration map of Turkey, Eng Geol, 74, 265-291, 2004.

Youd, T. L., Idriss, I. M., Andrus, R. D., Arango, I., Castro, G., Christian, J. T., Dobry, R., Finn, W. D. L., Harder, L. F., Hynes, M. E., Ishihara, K., Koester, J. P., Liao, S. S. C., Marcuson, III, W.F., Martin, G. R., Mitchell, J. K., Moriwaki, Y., Power, M. S., Robertson, P. K., Seed, R. B., and Stokoe, II. K. H.: Liquefaction resistance of soils: Summary report from the 1996 NCEER and 1998 NCEER/NSF workshops on evaluation of liquefaction resistance of soils, J. Geotech. Geoenviron. Eng., 817-833, 2001. 